\title{
ARTICLE
}

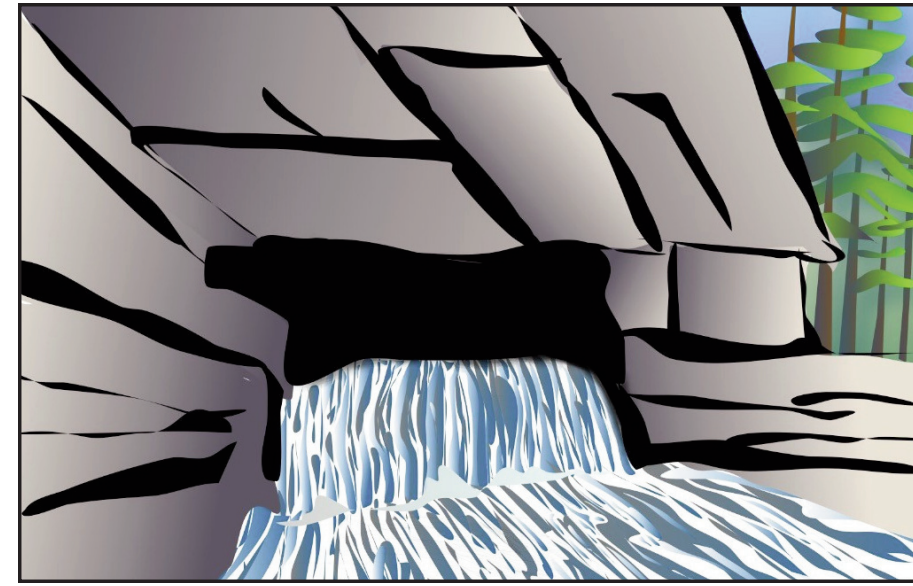

\section{An Overview of the Karst Areas in British Columbia, Canada}

Tim R. Stokes ${ }^{1}$ and Paul A. Griffiths ${ }^{2}$

\author{
${ }^{1}$ Earth Science Department, Vancouver Island University \\ 900 Fifth Sreet, Nanaimo, British Columbia, V9R 5S5, Canada \\ E-mail: tim.stokes@viu.ca
}

2544 Springbok Road, Campbell River

British Columbia, V9W 8 A2, Canada

\section{SUMMARY}

Karst is a three-dimensional landscape that occurs in soluble bedrock (typically limestone, marble, dolostone, gypsum or halite) and is defined by a solutionally weathered surface, a subsurface drainage system (where conduit-flow dominates), and underground openings and caves. Karst can host unique flora and subsurface fauna, as well as a wide range of other scientific, recreational and cultural values. Karst and potential karst areas underlie approximately $10 \%$ of British Columbia (BC), but the distribution and extent of this landscape has yet to be fully explored and delineated. Some of the most extensive and well-developed karst areas occur within the forested limestone areas of coastal BC, such as on Vancouver Island and Haida Gwaii, where numerous surface karst features and caves are known. Karst in the interior plateau regions of British Columbia is less well known, being in part covered by thick deposits of glacial materials. Alpine karst regions are most apparent in the Rocky Mountains where there are limestone plateaus, karst drainages and cave systems that have close connections to past and present glacial systems. Mapping of karst is a critical component for any land-use or resource development activity in all regions of British Columbia, as the environmental impacts on karst and its associated values are potentially significant. The regional distribution of karst in BC is not well mapped, with only an office-based reconnaissance karst potential map (1:250,000-scale) and a related database completed in 1999. A renewed effort should now be made to better map karst across British Columbia using digital bedrock mapping data released in 2017, combined with more recent satellite imagery and improved field knowledge.

\section{RÉSUMÉ}

Le karst est un paysage tridimensionnel qui se présente dans le substrat rocheux soluble (généralement calcaire, marbre, dolomite, gypse ou halite) et est défini par une surface altérée par dissolution, un système de drainage souterrain (où l'écoulement par conduit domine) et des ouvertures et cavernes souterraines. Le karst peut abriter une flore et une faune souterraine unique, ainsi qu'une grande variété d'autres ressources scientifiques, de loisir et culturelles. Les zones karstiques et potentiellement karstiques constituent environ 10\% de la surface de la Colombie-Britannique, mais la répartition et l'étendue de ce paysage n'a pas été complètement explorées et circonscrites. Certaines des zones karstiques les plus étendues et les mieux développées se trouvent dans les calcaires des zones calcaires boisées de la côte de la Colombie-Britannique, telles que l'île de Vancouver et l'archipel de Haida Gwaii, où l'on connait de nombreuses caractéristiques karstiques de surface et des cavernes. Le karst des régions des plateaux intérieurs de la Colombie-Britannique est moins bien connu, étant en partie recouvert d'épais dépôts de matériaux glaciaires. Les régions karstiques alpines sont plus apparentes dans les montagnes Rocheuses où se trouvent des plateaux calcaires, des bassins de drainage karstiques et des systèmes de cavernes étroitement liés aux systèmes glaciaires passés et contemporains. La cartographie du karst est une constituante essentielle de toute activité d'utilisation du terrain ou de développement des ressources dans toutes les régions de la Colombie-Britannique, car les impacts environnementaux sur le karst et ses bénéfices associés sont potentiellement importants. La distribution régionale et les caractéristiques des karsts en ColombieBritannique ne sont pas bien cartographiées, avec seulement une carte de reconnaissance du potentiel karstique établie par 
une étude de bureau (à l'échelle de 1/250 000) et une base de données associée, complétées en 1999. Il faut aujourd'hui améliorer la cartographie de karsts en Colombie-Britannique en utilisant les données numériques de cartographie du substrat rocheux publiées en 2017, combinées avec des images satellite plus récentes et à une meilleure connaissance du terrain.

\section{INTRODUCTION}

'Karst' is a generic term used to describe a topography that is formed primarily by the dissolution of bedrock and is internally drained. For simplicity, this one word is used in preference to 'karst land' or 'karst landscapes.' It implies not only the physical aspects of the karst system (i.e. soil and bedrock), but also the other attributes of karst: biota, air and water. The primary objectives of this paper are to provide an overview of what is currently known about the distribution and general characteristics of karst in British Columbia (BC), to outline the different karst types across the province, to provide some preliminary ideas on karst development in the region and to identify future needs and approaches for better land-use management of karst in $\mathrm{BC}$ (e.g. improved karst mapping and karst inventories). A key goal of this paper is to bring together, in one summary document, the main resources and references for karst in $\mathrm{BC}$ and provide a starting point for those wishing to delve deeper into this important and valuable resource. The paper is not intended as an exhaustive bibliography covering all aspects of karst in the province but aims instead to identify some of the key facets and issues. As with any review, there is the potential for omissions. The authors would be happy to be informed of these.

It is estimated that $10 \%$ of $\mathrm{BC}$ is underlain by carbonate bedrock with the potential to develop as karst. This number is derived from an analysis of the proportion of soluble bedrock within the various carbonate units of $\mathrm{BC}$ and is detailed in Table 1. It is also possible that some areas of carbonate bedrock are unaccounted for and may occur outside those identified. Overall, the most extensive areas of carbonate bedrock occur in the Rocky Mountains, with lesser amounts in BC's interior and along the west coast.

From geomorphic and hydrologic perspectives, karst is best defined as a three-dimensional landscape (Fig. 1) that develops from the dissolving action of water on soluble bedrock such as limestone, marble, dolostone, gypsum or halite. Theoretically, all bedrock can be considered soluble, but karst rock types are significantly more soluble by several orders of magnitude than non-karst bedrock, such as granite. The resulting landscape is characterized by solutional (fluted and pitted) bedrock surfaces, shafts, karst sinkholes (commonly referred to as dolines in Europe), sinking streams, springs, underground drainage systems, deep flooded (phreatic) networks and subsurface openings of all sizes, including those that we as humans enter, better known as caves.

Karst should be considered as an interconnected and functioning ecosystem within which a delicate balance occurs between the bedrock, soil, water, air and biota (Fig. 2). Karst biota can be highly specialized, ranging from calcium-loving

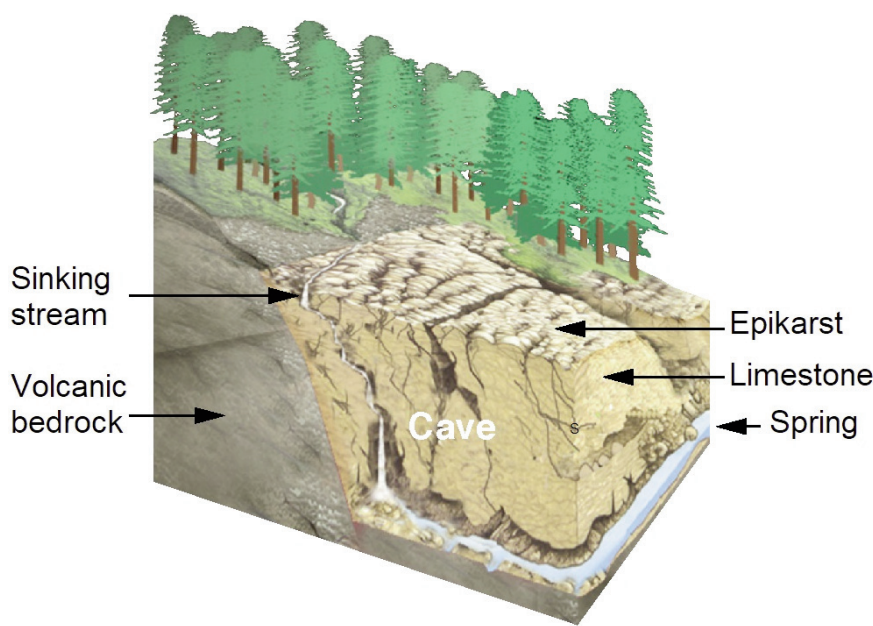

Figure 1. Forest-covered karst of British Columbia can be characterized as a threedimensional landscape with subsurface openings and drainage. Note that the forest and soil cover is removed on the right side of the image for illustration purposes.
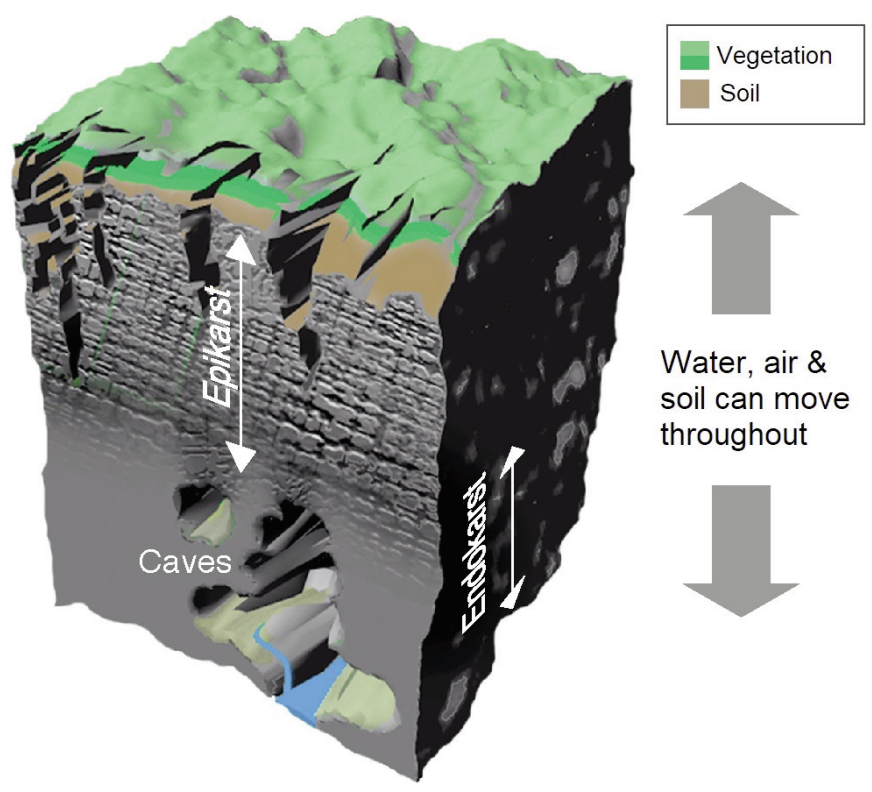

Water, air \& soil can move throughout

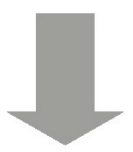

Figure 2. Representation of karst as a functioning system with open connections between surface, epikarst and endokarst, allowing free movement of soil, air, water and biota.

plant life on the surface, specially adapted fauna living in the subsurface environment, to microbes involved in the karstification process (Palmer 2007). Beyond these natural attributes, karst systems can also have considerable historical, cultural, aesthetic, scientific and educational values (Gunn 2003).

The first comprehensive research on karst in $\mathrm{BC}$ was initiated in the 1960's by Derek Ford and the Karst Research Group at McMaster University, Ontario. This research was extensive considering the size of the province and covered a broad range of topics across $\mathrm{BC}$ and elsewhere in Canada (Ford 1993). Examples of karst investigations in British Columbia include the sinking streams of Mount Tupper (Ford 1967), gypsum karst near Canal Flats (Wigley et al. 1973), alpine karst in the Mount Castleguard-Columbia Icefield area 
Table 1. A compilation of rating criteria for 'karst polygons' of British Columbia, as derived from reconnaissance karst mapping (Stokes 1999).

\begin{tabular}{|c|c|c|c|c|c|c|}
\hline $\begin{array}{l}\text { Karst Potential Polygons } \\
\text { with Ratings for Criteria } \\
\# 1 \text { and } \# 2^{1}\end{array}$ & $\begin{array}{c}\text { Area of Karst } \\
\text { Polygons } \\
\left(\mathrm{km}^{2}\right)\end{array}$ & $\begin{array}{l}\text { Percent of } \\
\text { Total Area }\end{array}$ & $\begin{array}{l}\text { Adjusted Area of } \\
\text { Karst Applying } \\
\text { Criterion \#1 } 1^{2}\end{array}$ & $\begin{array}{c}\text { Percent } \\
\text { Adjusted } \\
\text { Area } \\
\end{array}$ & $\begin{array}{c}\text { Number of } \\
\text { Polygons }\end{array}$ & $\begin{array}{c}\text { Percent of } \\
\text { Polygons }\end{array}$ \\
\hline Primary - High $\left(\mathrm{P}^{\mathrm{H}}\right)$ & 28317.5 & $23.40 \%$ & 28317.5 & $34.03 \%$ & 2625 & $34.70 \%$ \\
\hline Primary - Moderate $\left(\mathrm{P}^{\mathrm{M}}\right)$ & 35545.6 & $29.40 \%$ & 35545.6 & $42.72 \%$ & 1977 & $26.10 \%$ \\
\hline Primary - Low $\left(\mathrm{P}^{\mathrm{L}}\right)$ & 961.6 & $0.80 \%$ & 961.6 & $1.16 \%$ & 120 & $1.60 \%$ \\
\hline Secondary - High $\left(\mathrm{S}^{\mathrm{H}}\right)$ & 1006.7 & $0.80 \%$ & 503.4 & $0.60 \%$ & 93 & $1.20 \%$ \\
\hline Secondary - Moderate $\left(\mathrm{S}^{\mathrm{M}}\right)$ & 19145.8 & $15.80 \%$ & 9572.9 & $11.51 \%$ & 758 & $10.00 \%$ \\
\hline Secondary - Low $\left(\mathrm{S}^{\mathrm{L}}\right)$ & 3730.2 & $3.10 \%$ & 1865.1 & $2.24 \%$ & 394 & $5.20 \%$ \\
\hline Tertiary - High $\left(\mathrm{T}^{\mathrm{H}}\right)$ & 1792.2 & $1.50 \%$ & 358.4 & $0.43 \%$ & 8 & $0.10 \%$ \\
\hline Tertiary - Moderate $\left(\mathrm{T}^{\mathrm{M}}\right)$ & 22171.2 & $18.30 \%$ & 4434.2 & $5.33 \%$ & 932 & $12.30 \%$ \\
\hline Tertiary - Low $\left(\mathrm{T}^{\mathrm{L}}\right)$ & 8231.4 & $6.80 \%$ & 1646.3 & $1.98 \%$ & 661 & $8.70 \%$ \\
\hline Totals & $120,902.2$ & $100 \%$ & $83,205.0$ & $100 \%$ & 7,568 & $100 \%$ \\
\hline
\end{tabular}

Percent of Potential Karst in BC Assuming BC Total Land Area of $944,735 \mathrm{~km}^{2}$

\title{
$12.80 \%$
}

$8.81 \%$

\begin{abstract}
Criterion \#1 is the proportion of soluble bedrock in the geological unit and included qualitative estimates of Primary (> 50\% of unit), Secondary ( $20-49 \%$ of unit), and Tertiary (5-19\% of unit). Criterion \#2 is the likely intensity of karst development in the soluble bedrock providing ratings of High, Moderate and Low. High indicates a well-developed karst landscape with surface features common and linked to a subsurface drainage system; Moderate some karst development with occasional surface karst features and a definite subsurface drainage system, and Low having minor surface solutional weathering on bedrock surfaces, few to no surface features, with subsurface drainage less evident.
\end{abstract}

${ }^{2}$ The adjusted total area using Criterion \#1 to calculate the polygon areas is based on $100 \%$ for Primary, $50 \%$ for Seconday and $20 \%$ for Tertiary. Note, the percentages for Criterion \#1 were originally derived from qualitative estimates provide by geologists familar with bedrock units, map legends and published descriptions of units (Stokes 1999). Hence, there should be care in how data is analyzed and applied.

(Ford 1983b), forested karst in Northern Vancouver Island (Harding and Ford 1993), karst hydrology of White Ridge on Vancouver Island (Ecock 1984), and karst development and groundwater flow on Northern Vancouver Island (Mills 1981). Research on karst caves, such as those on Vancouver Island, provided information on the likely ages of cave sediments and speleothems (cave mineral formations like stalagmites and stalactites), as well as past environmental and climatic conditions (e.g. Ford 1975; Gascoyne et al. 1981; Latham et al. 1982; Zhang et al. 2008; Marshall et. al. 2009). Examples of karst research in the Canadian Rocky Mountains included work on karst springs and regional hydrology (Worthington 1991; Worthington and Ford 1995; Smart 1997), as well as caves and their speleothem materials (e.g. Harmon et al. 1977; Yonge et al. 2014).

Land-use and resource development activities can directly or indirectly impact the surface and the subsurface of karst due to its inherent connectivity and openness. Equally, karst can pose potential hazards for these activities due to subsidence or alteration to subsurface drainage. Forestry is one of the most widespread land-use activities on the karst in $\mathrm{BC}$ and is an example of why there has been, and continues to be, a need for an improved understanding of karst. Caves were the prime focus in the protection of forested karst areas until the late 1990s when the BC Ministry of Forests first announced a systems-based approach to karst management (BC Ministry of Forests 1997; Beedle 1997). This was followed by an investiga- tion into karst inventory systems for BC (Stokes and Griffiths 2000a), and the concurrent development of the Karst Inventory Standards and Vulnerability Assessment Procedures for British Columbia (RISC 2003) and the Karst Management Handbook for British Columbia (BC Ministry of Forests 2003).

It is now widely accepted that any land-use or resource development activities that occur on or near karst require consideration of the environmental impacts on karst systems (both short and long term disturbances), the effects on karst aquifers and their catchments (including contributing nonkarst drainage areas), and the potential for karst-related geohazards (van Beynen 2011). Other resource development activities in BC, such as alternative energy projects, dams, highways, mining and oil and gas extraction now consider karst issues in their planning (Stokes 2013).

\section{KARST AND THE SOLUBLE BEDROCK UNITS OF BRITISH COLUMBIA}

Soluble bedrock units (primarily carbonate rocks) are found in all five tectonic regions of $\mathrm{BC}$ including the Insular Belt, the Coast Belt, the Intermontane Belt, the Omineca Belt and the Foreland Belt (Fischl 1992; Fig. 3). Each of these tectonic belts is made up of various geologic terranes and super-terranes that were accreted to North America during the Mesozoic and include extensive regions of deformation and magmatism (Wheeler and McFeely 1991). The five tectonic belts closely match the main physiographic areas of BC. From west to east, 


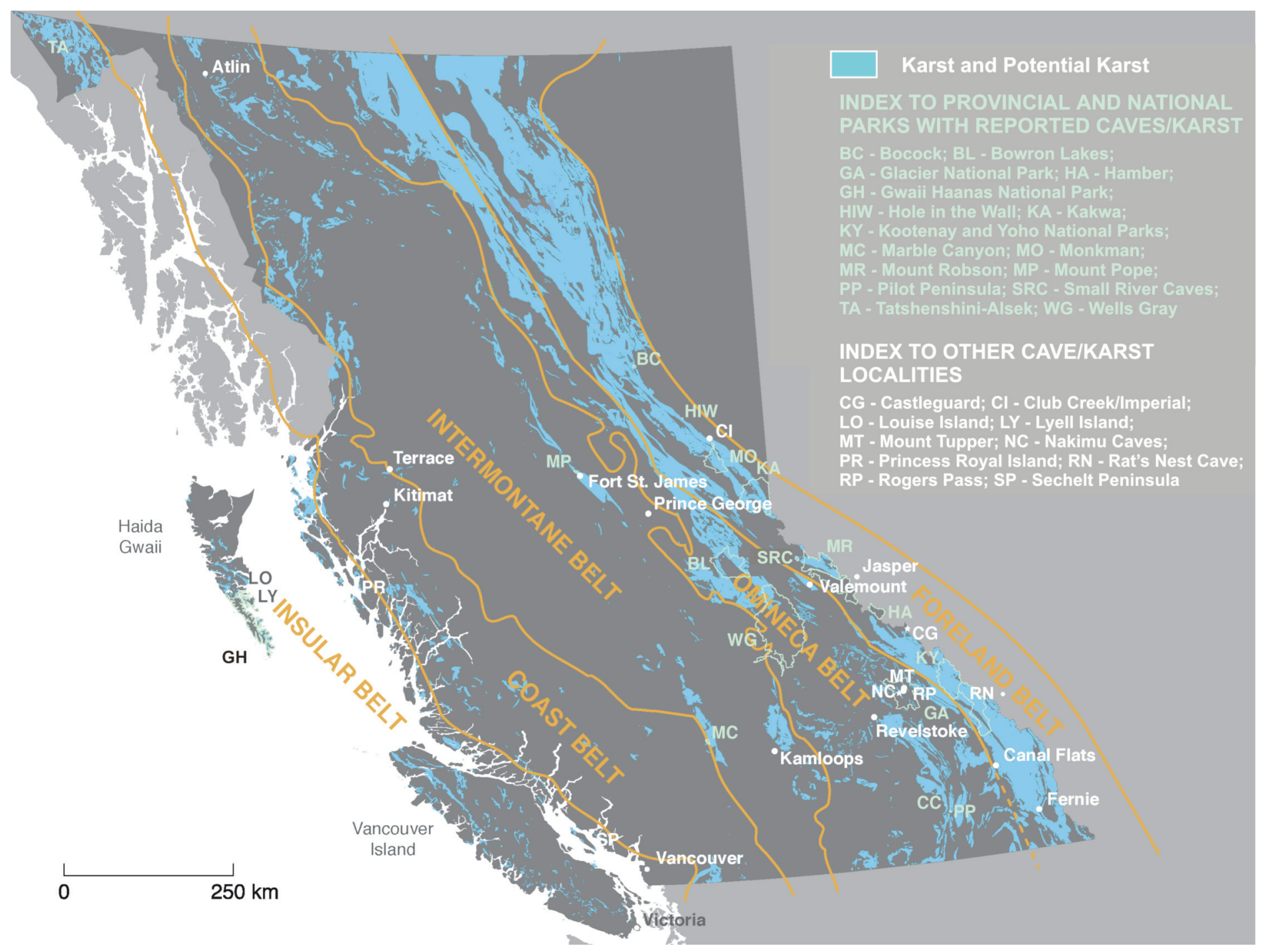

Figure 3. The five major tectonic belts identified in British Columbia showing the areas of carbonate bedrock that contain karst and potential karst.

these are Vancouver Island and Haida Gwaii, the Coast Mountains, the interior plateaus and mountains, the ColumbiaOmineca-Cassiar Mountains and the Rocky Mountains (Church and Rider 2010; Fig. 4). Limestone is the most common type of karst bedrock found within all five tectonic belts, and dolostone (often termed dolomite) is generally confined to the Rocky Mountains. Gypsum karst is less common, with occurrences in southeastern BC (mostly in Devonian sequences near Canal Flats), minor amounts in the Rocky Mountains, and some small occurrences in northwest BC. Most of the carbonate units in BC are Triassic, Permian and Carboniferous in age, with older Cambrian to Devonian carbonate units found in the Rocky Mountains (Fischl 1992). Table 2 summarizes the main carbonate-bearing units in which evidence for karst development has been reported, and subdivides them based on their respective tectonic belt, geological age and soluble bedrock type. Note, that not all individual units described below are listed in Table 2 due to space limitations.

The determination as to whether a given carbonate bedrock unit exhibits karst characteristics is not always easy, and the common term 'karst potential' is often used to describe in a qualitative way the likelihood that a geological unit will develop karst (e.g. Weary and Doctor 2014). For karst to be definitively identified in a given area it should include some if not all of the following elements: a solutionally weathered surface, surface karst features, subsurface openings (which do not have to be caves), and an underground drainage system.

Regional mapping of karst in BC was first carried out on Vancouver Island in 1995 (Stokes 1995), and was followed by reconnaissance (1:250,000-scale) karst potential mapping and inventory for all of $\mathrm{BC}$, which was based on the first available digital bedrock map compilation for the province (Stokes 1999). This study identified 345 soluble bedrock units (formations) in BC with karst potential - a total of 7568 polygons for the whole province (Table 1). These polygons were rated for three criteria. The first criterion was the proportion of soluble bedrock in the geological unit, defined as Primary $(>50 \%)$, Secondary $(20-50 \%)$, or Tertiary $(<20 \%)$. The second criterion was the likely intensity of karst development in the soluble 


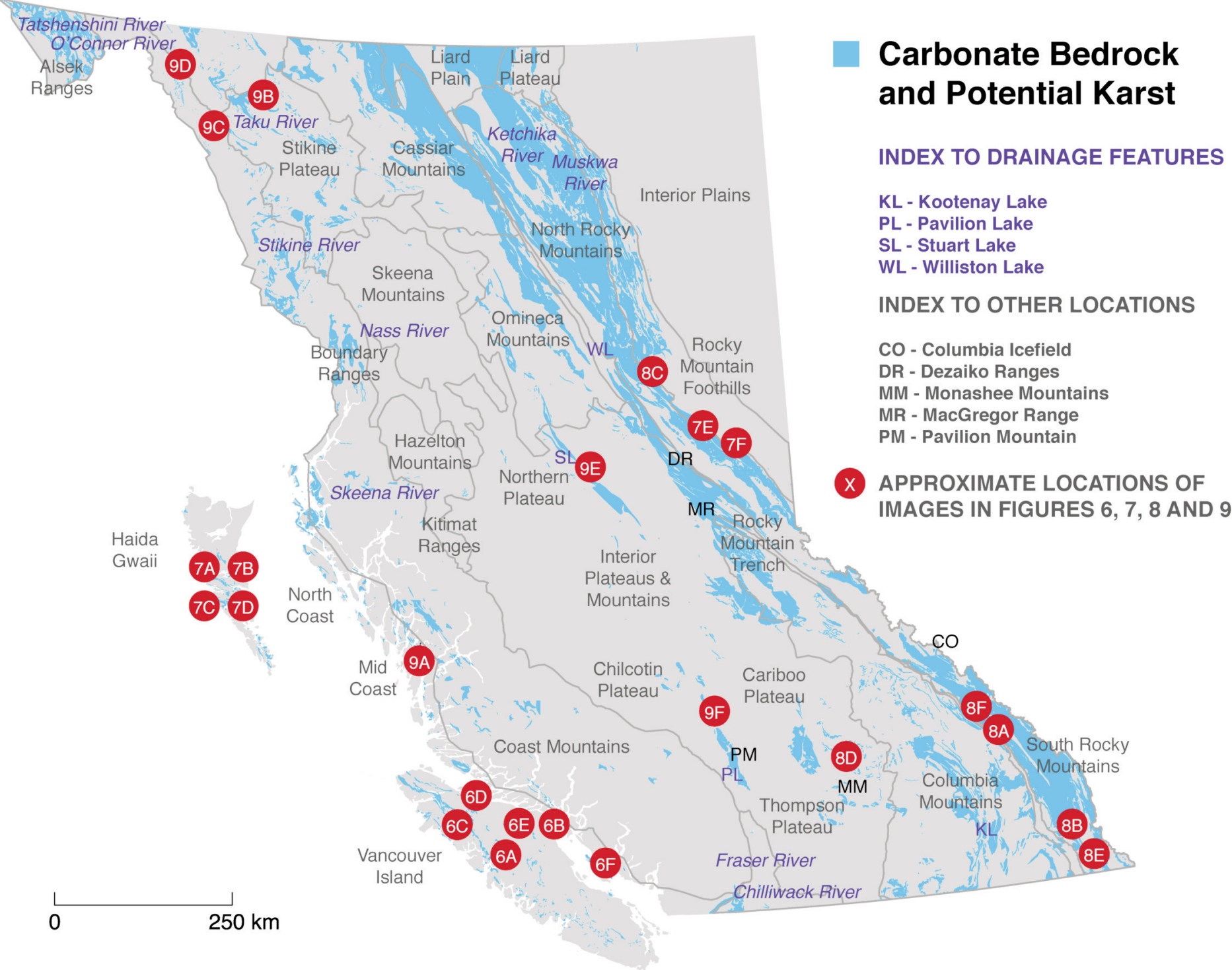

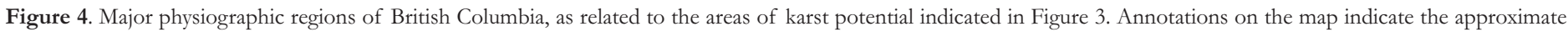
locations of photos depicting karst features and landscapes in figures 6, 7,8 and 9 .

bedrock unit, defined as Low, Moderate or High. The third criterion was the presence or absence of caves or other karst landform features. Approximately one-third of the soluble bedrock units identified include $>50 \%$ soluble bedrock (Primary) and have a High intensity rating for karst development (see Table 1). However, only $15-20 \%$ of these potential karst areas have confirmed karst features or caves, and most occur on the coast or in the southern parts of BC. From this analysis, it is apparent that there are many areas of soluble bedrock in BC that likely have well-developed karst, even though such features have not yet been verified by field work. Geographic data and GIS shapefiles for the reconnaissance karst potential mapping of British Columbia (Stokes 1999) can be directly downloaded from Data BC (https://data.gov.bc.ca/).

The five tectonic belts of BC (Fig. 3) provide a good basis for subdividing the karst areas according to their different geological settings. The physiographic regions of $\mathrm{BC}$ that broadly correspond with these tectonic belts vary in terms of their local climate (rainfall and temperature), topography, elevation, surficial materials and vegetation cover. All of these attributes play an important role in the development of karst. In the following sections, the main geological units known to host caves and other karst features within each of the tectonic belts are described, and important examples are then listed and discussed. The level of information and knowledge on karst within individual geological units varies due to the large areal extent of the province, and the dispersed locations of population centres. Areas located close to population centres are generally better known than the more remote areas. In some cases, the evidence for karst development is extensively supported by referenced sources, government documents, and other published or unpublished reports. In other cases, evidence is more fragmentary and based largely on unpublished observations (e.g. field notes and photos) by the authors and/or information 
Table 2. A summary of the principal carbonate-bearing units in British Columbia according to tectonic belts and geological age. Note, not all geological units referenced in text are listed.

\begin{tabular}{|c|c|c|c|c|c|}
\hline Age & Insular Belt & Coast Belt & Intermontane Belt & Omineca Belt & Foreland Belt \\
\hline \multirow[t]{5}{*}{ Triassic } & Parson Bay Fm. & $\begin{array}{l}\text { Limestone and marble } \\
\text { pendants of Wrangellia }\end{array}$ & Nicola Group & & Baldonnel Fm. \\
\hline & Quatsino Fm. & & Sinwa Fm. & & Pardonet Fm. \\
\hline & Upper Karmutsen Fm. & & & & \\
\hline & Sadler Fm. & & & & \\
\hline & Peril Fm. & & & & \\
\hline \multirow[t]{3}{*}{ Permian } & Mount Mark Fm. & $\begin{array}{l}\text { Limestone and marble } \\
\text { pendants of Alexander }\end{array}$ & Marble Canyon Fm. & & \\
\hline & & & Teslin Fm. & & \\
\hline & & & $\begin{array}{c}\text { Unnamed Terrace } \\
\text { Limestone }\end{array}$ & & \\
\hline \multirow[t]{5}{*}{ Carboniferous } & & Chilliwack Formation & Harper Ranch Group & Milford Fm. & Ketchika Group \\
\hline & & & Cache Creek Group & Index Fm. & Livingstone $\mathrm{Fm}$. \\
\hline & & & Horsefeed Fm. & Broadview Fm & Rundle Group \\
\hline & & & & & Prophet Fm. \\
\hline & & & & & Banff Fm \\
\hline \multirow[t]{4}{*}{ Devonian } & & & & & Exshaw Fm. \\
\hline & & & & & Palliser Fm. \\
\hline & & & & & Dunedin Fm \\
\hline & & & & & Stone Fm \\
\hline \multirow[t]{3}{*}{ Silurian } & & & & & Whitehorse Fm. \\
\hline & & & & & Mount Wilson Fm. \\
\hline & & & & & Nonda Fm. \\
\hline \multirow[t]{3}{*}{ Ordovician } & & & & & Skoki Fm. \\
\hline & & & & & Beaverfoot Fm. \\
\hline & & & & & Chushina Fm. \\
\hline \multirow[t]{3}{*}{ Cambrian } & & & & Mural Fm. & Cathedral Fm \\
\hline & & & & Cunningham Fm. & Badshot Fm. \\
\hline & & & & Rosella Fm & Jubilee Fm. \\
\hline Proterozoic & & & & Espee Fm. & \\
\hline
\end{tabular}

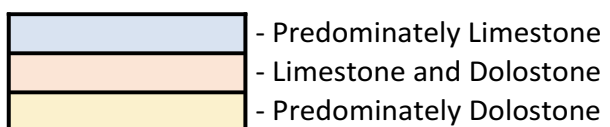

from other reliable sources. The following sections contain many locality names, and it is difficult to indicate all of these accurately on the page-size maps used in this paper. However, the most important localities are indicated by abbreviations in Figures 3, 4 and 5, and those that are not indicated can be located through examination of more detailed topographic maps. Karst features in British Columbia for each of the tectonic belts are illustrated by photographs in figures 6, 7, 8 and 9.

\section{Insular Belt}

The Insular Belt is comprised of the islands and coastal areas of mainland BC (Fig. 3), which are mostly made up of rocks of the Wrangellia Terrane, and to a lesser extent the Alexander Terrane (Wheeler and McFeely 1991). These terranes are bounded to the east by granitoid rocks (e.g. quartz-diorite and granodiorite) of the Coast Belt. The Insular Belt can be subdivided into three geographic areas: Vancouver Island, Haida
Gwaii (formerly known as the Queen Charlotte Islands), and by the mid- and north-coast of BC (Fig. 3).

The distribution and extent of karst on Vancouver Island is relatively well known. Most karst occurs within one of three soluble bedrock units - the Quatsino, Parson Bay and Mount Mark formations. These units form linear zones that are typically tens of kilometres long and only a few kilometres wide in the north and central parts of the island (Fig. 5). These rocks are typically moderately dipping, and comprised of thick-bedded, white to light grey limestone of the Quatsino Formation, overlain by interbedded of dark grey limestone and black shale of the Parson Bay Formation. The older Mount Mark Formation occurs as smaller zones comprised of thick fossiliferous beds of crinoidal limestone, which are typically more affected by folding and faulting than the younger units. Much of the karst of Vancouver Island is forest-covered and occurs along lower valley bottoms (e.g. Tashish River), on broad benches and plateaus (e.g. Gibson Plateau) and middle to upper slopes 


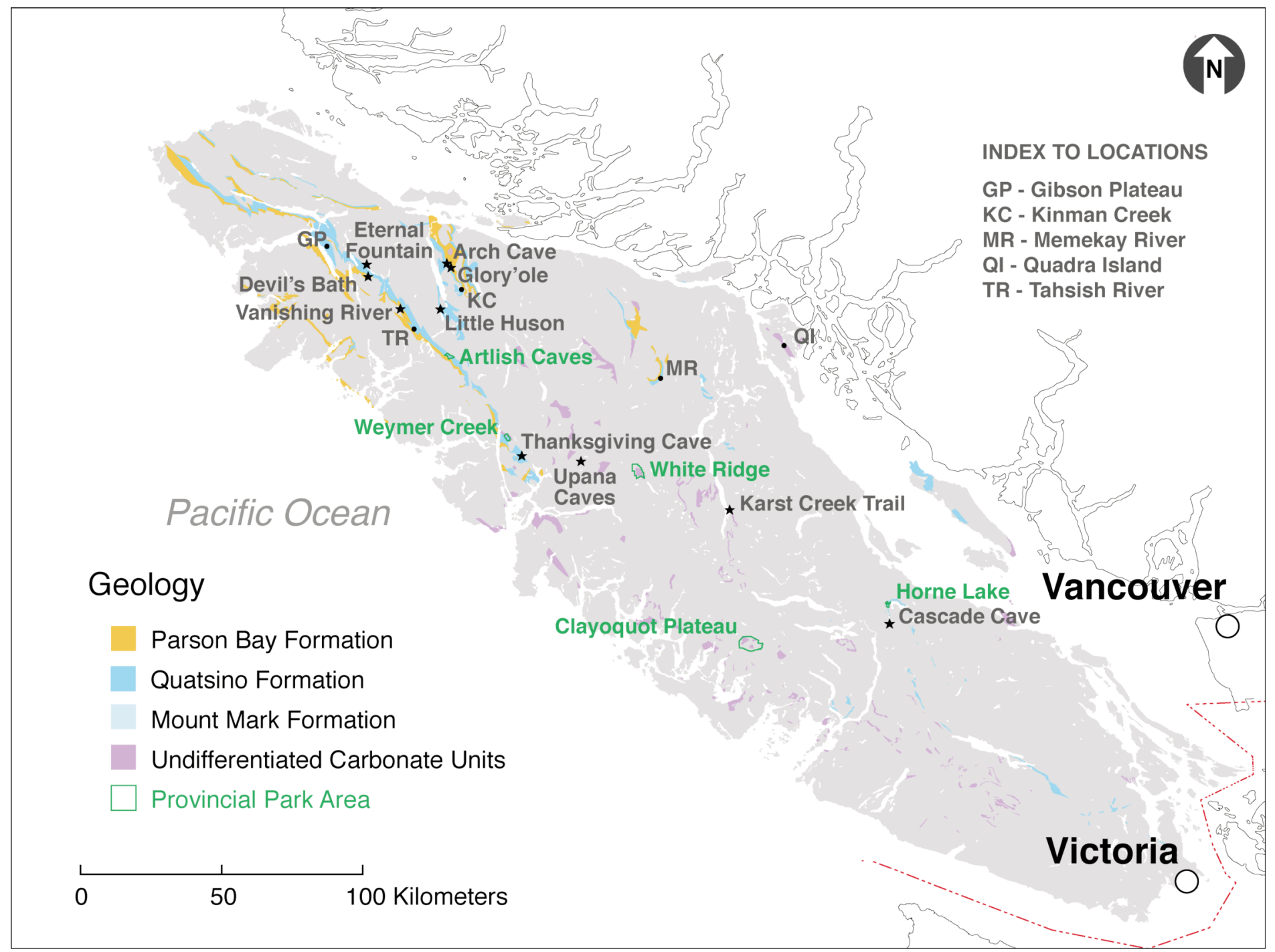

Figure 5. Carbonate units on Vancouver Island, British Columbia, and the locations of important karst areas discussed in the text.

(e.g. Kinman Creek, see Stokes et al. 2010, 2013). A few karst areas occur in alpine regions (e.g. Strathcona Provincial Park; Fig. 6A), whereas others occur near or along shorelines, and represent littoral (shoreline) karst (e.g. Texada Island; Fig. 6F). Karst sinkholes (dolines) of varying dimensions are the most common karst feature encountered (Fig. 6B, D), with sinkhole clusters typically found on benches (Ramsey 2015). Other features include sinking streams (e.g. Vanishing River), karst springs (e.g. Eternal Fountain), karst canyons (e.g. Memekay River; Fig. 6E), and arches (e.g. Little Huson Caves; Fig. 6C). Numerous cave systems occur throughout Vancouver Island, with varying levels of exploration and mapping completed; prominent examples include Thanksgiving Cave, Glory'ole Cave and Arch Cave (Fig. 5). Several provincial parks dedicated to karst landscapes are present on Vancouver Island (e.g. Clayoquot Plateau, Weymer Creek, Artlish Caves, and White Ridge) and Horne Lake Caves Provincial Park. The latter is known for commercially operated cave tours. Several designated sites also highlight various aspects of karst, including the Devil's Bath and the Eternal Fountain (near Port Alice), Upana Caves (near Gold River), and the Karst Creek Trail in Strathcona Provincial Park.

The karst areas of Haida Gwaii have some similarities to Vancouver Island in that they are mostly forest-covered and occur in bedrock units of equivalent geologic age - the Sadler and Peril formations. The Sadler Formation is comprised of thick-bedded limestone (like the Quatsino Formation), whereas the Peril Formation is comprised of calcareous black shale and limestone (like the Parson Bay Formation). As on Vancouver Island, most of the karst development occurs in thickerbedded limestone (i.e. the Sadler Formation) with the formation of sinkholes, karst canyons, dry valleys, karst springs, and small-scale solution features (karren) on outcrop surfaces (see Fig. 7A to 7D, and Griffiths and Ramsey 2009). Most of the karst in Haida Gwaii archipelago occurs to the south including areas within the Gwaii Haanas National Park, Lyell Island and Louise Island. Caves in Haida Gwaii (and also on Vancouver Island) are known to contain valuable paleontological remains 

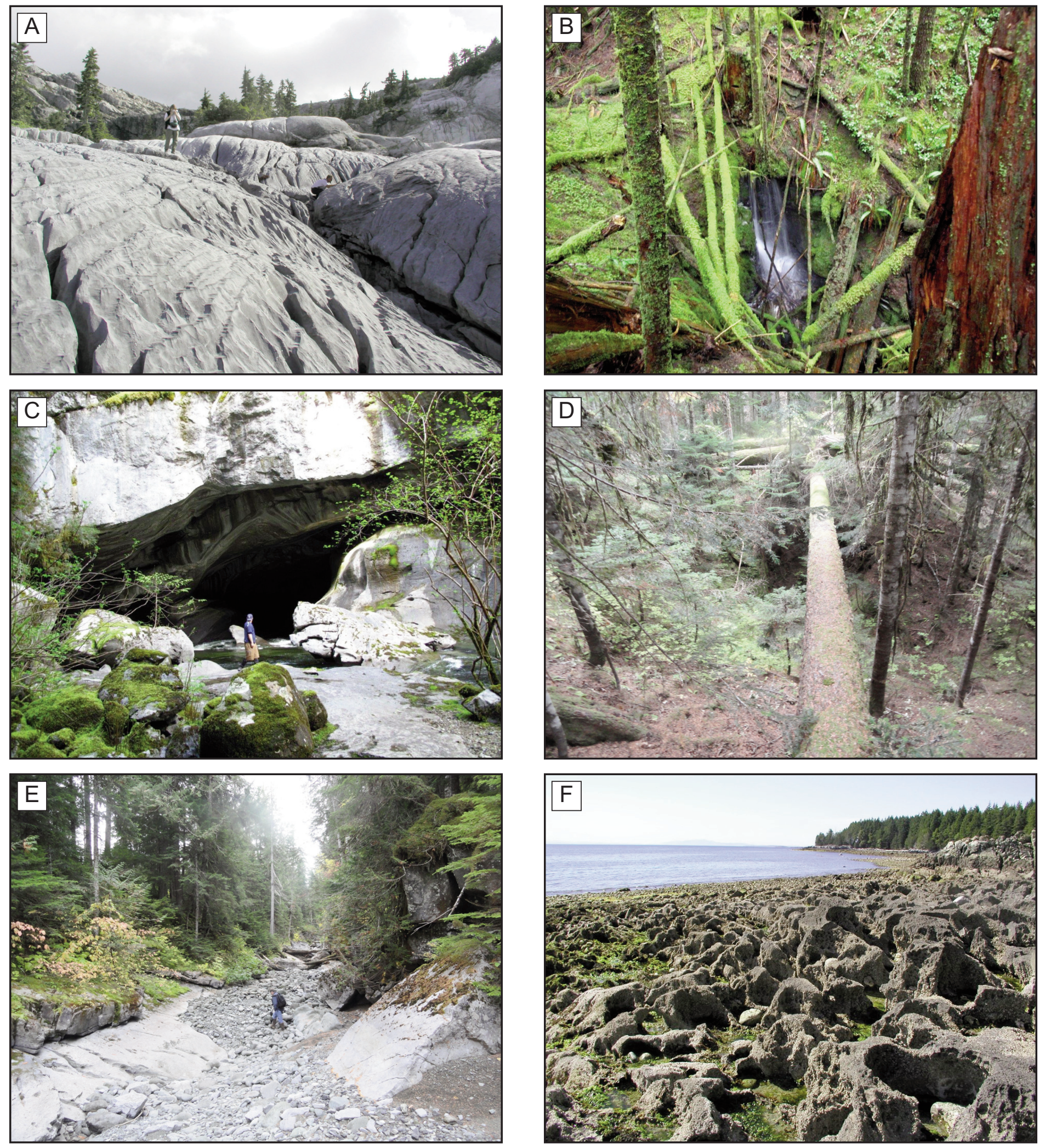

Figure 6. Karst features on Vancouver Island, British Columbia. A: Solutionally weathered limestone surface in alpine area near McNally Ridge, Central Vancouver Island. B: Karst spring appearing from the side of a forested sinkhole within second-growth of Quadra Island. C: Disappearing Atluck Creek at Little Huson Regional Park (Credit: Stewart Butler). D: Large sinkhole in Kinman Area with thick primary forest cover. E: Karst canyon along Memekay River during summer months. F: Solutionally weathered limestone on the shoreline of Texada Island.

http://www.geosciencecanada.ca 

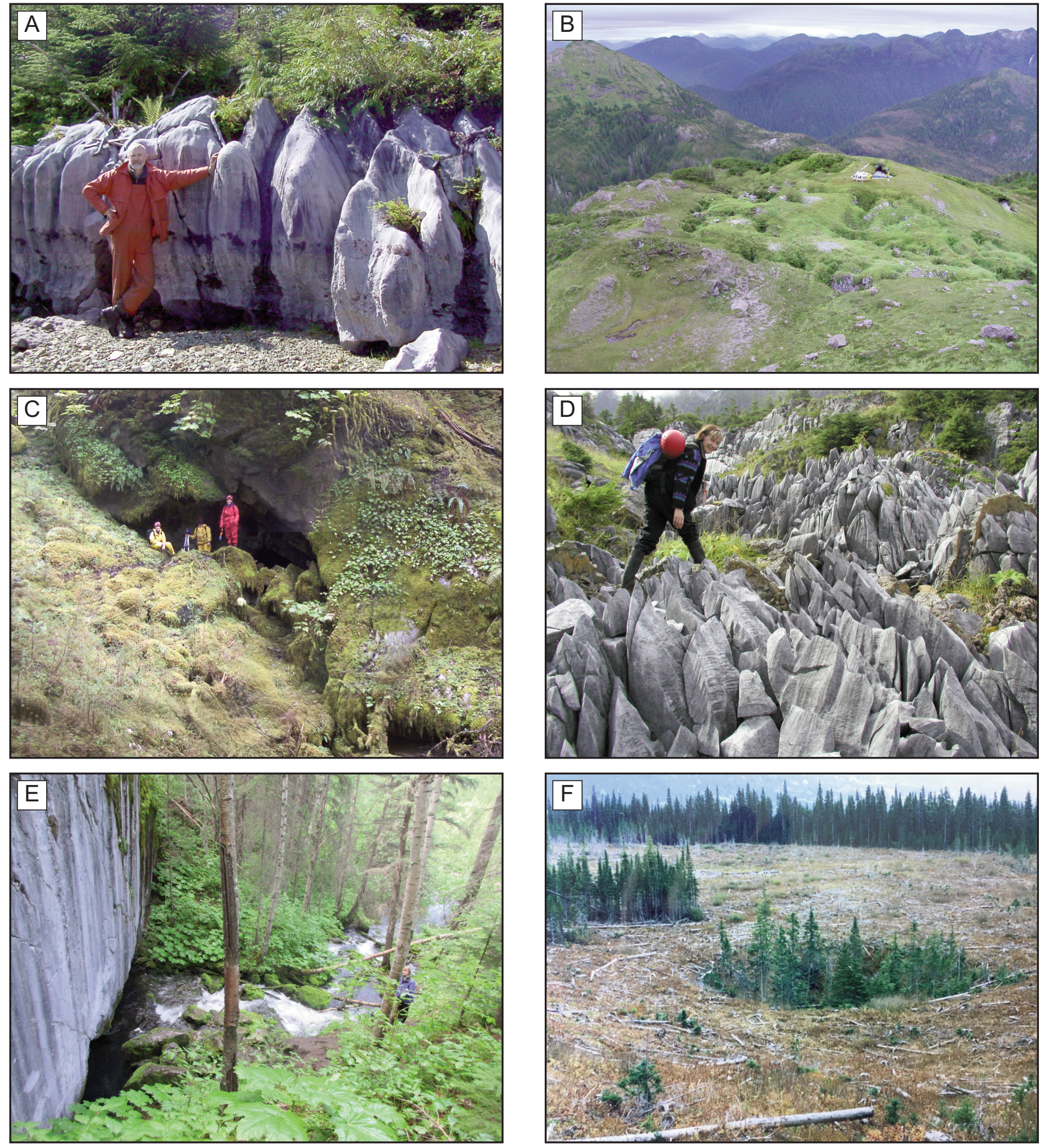

Figure 7. Karst features of Haida Gwaii and Canadian Rocky Mountains, British Columbia. A: Solutionally weathered epikarst exposure with karren features from Moresby Island, Haida Gwaii. Note, apparent narrowing of solutional openings towards base of outcrop. B: Upper elevation karst area with sinkhole cluster, Moresby Island, Haida Gwaii. C: Forested cave entrance, Moresby Island, Haida Gwaii. D: Solutionally weathered and frost shattered epikarst exposure in subalpine karst of Haida Gwaii. E: Karst spring at Hole-in-the-Wall Provincial Park, Chetwynd, BC (Credit: Charles Helm). F: Depression features in thickly mantled limestone of the Club Creek Area. Note, trees left within depressions, while surrounding areas harvested. 

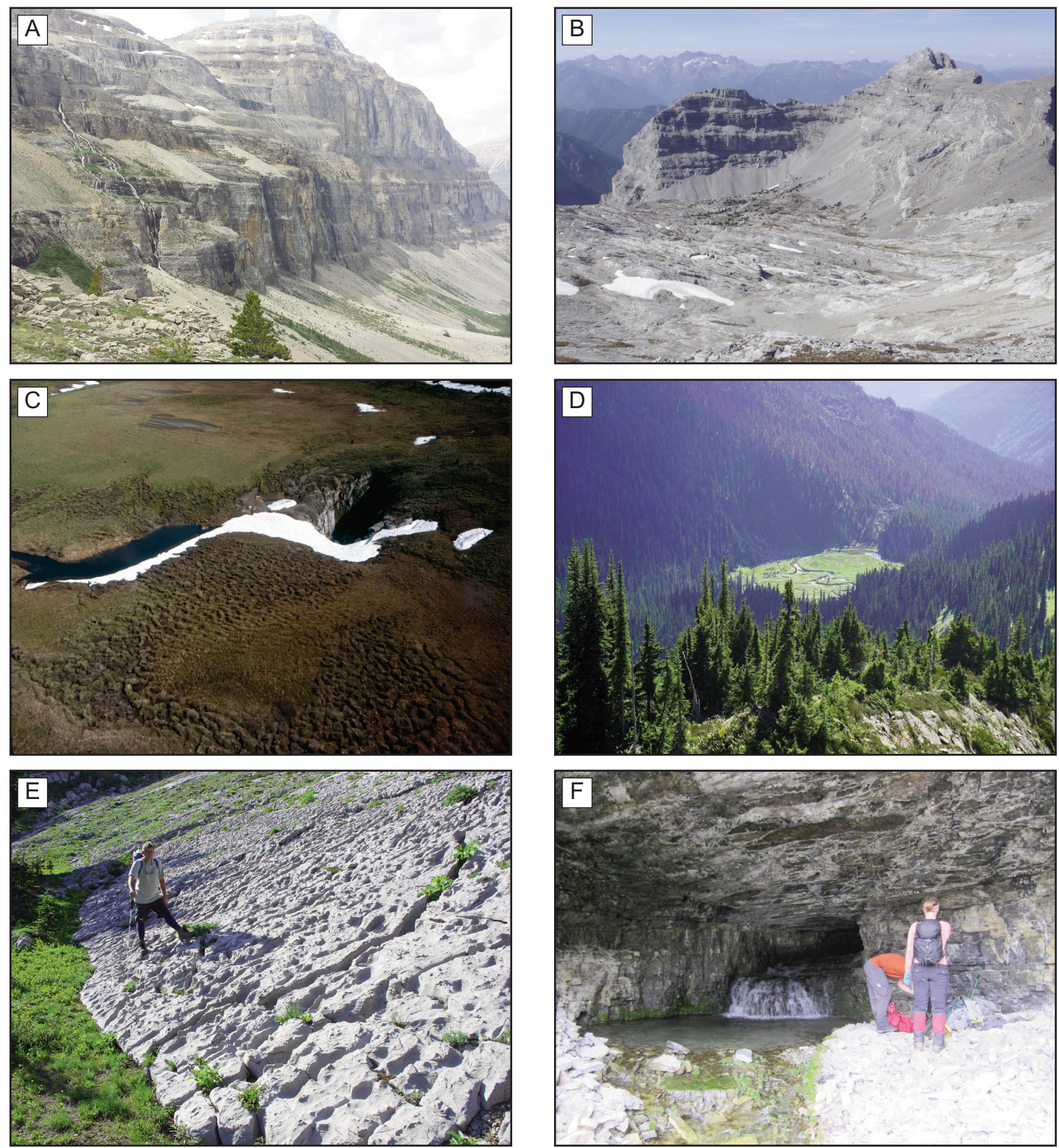

Figure 8. Karst landscape and features of the Columbia Mountains and Southern Canadian Rocky Mountains. A: Series of karst springs hosted in Middle to Upper Cambrian limestone near Mount Stanley, Kootenay National Park (Credit: EmmaYonge). B: Glacially scoured limestone plateau at Mount Bisaro (near Fernie); likely hosted within limestone of Banff, Exshaw and Palliser formations (Credit: Chas Yonge). C: Sinking stream and White Hole sink point in the Bocock Provincial Park; likely hosted in Carboniferous limestone and/or dolomite of the Charlie Lake, Baldonnel, Pardonet and Bocock formations (Credit: Chas Yonge). D: Polje and White Rabbit sink point (located to left of polje); likely hosted in marble pendants within the Monashee Complex/Mountains (Credit: Chas Yonge/Martin Davis). E: Solutional karren on limestone surface near Mount Doupe, Fernie. Features likely hosted within limestone of the Carboniferous Livingston Formation part of the Rundle Group (Credit: Chas Yonge). F: Karst spring and entrance to Her Majesty's Cave, Kootenay National park (Credit: Chas Yonge). 

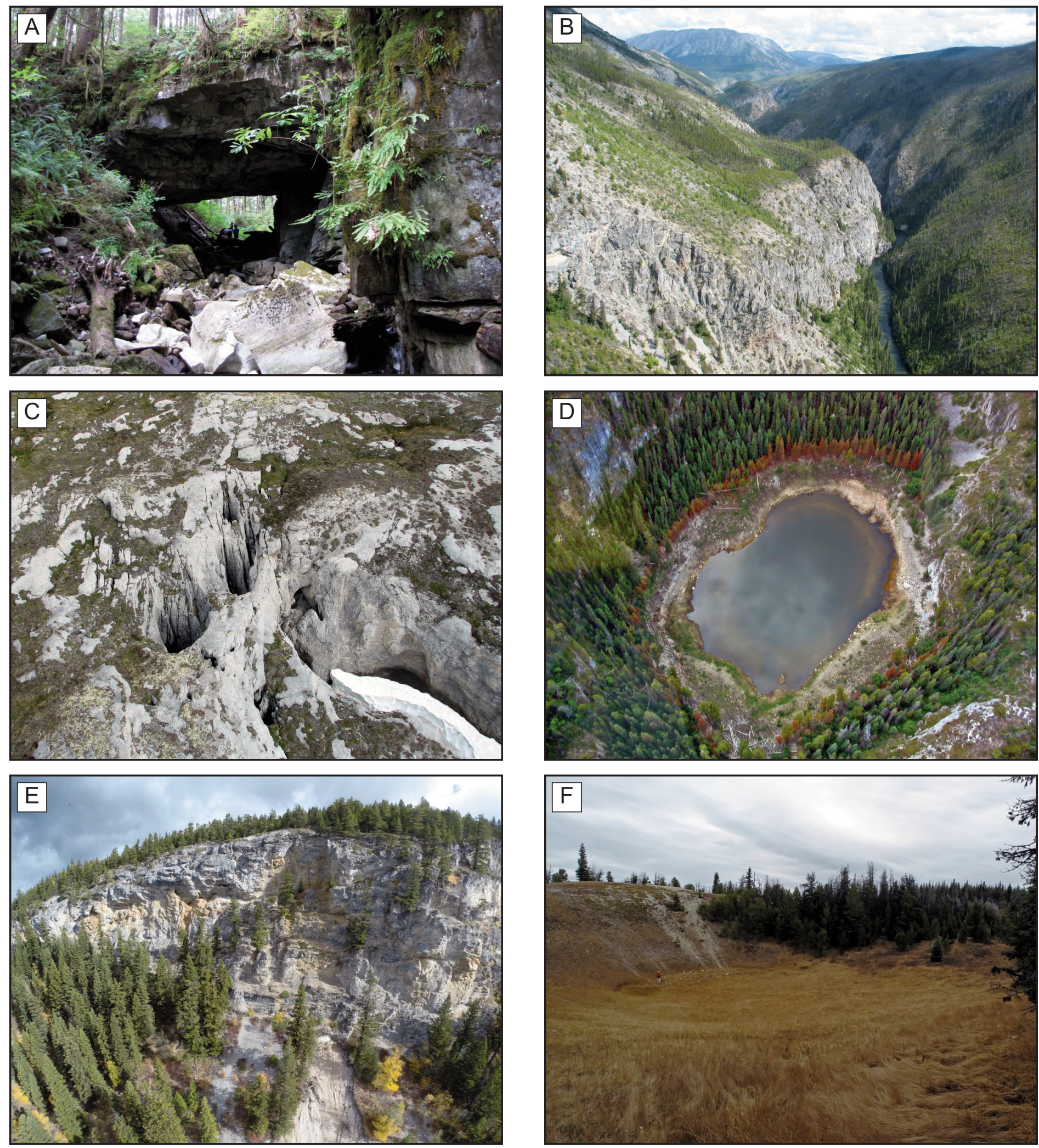

Figure 9. Karst landscapes and features of northern and northwestern British Columbia. A: Karst arch near Bella Bella; probably hosted in limestone/marble pendant of Alexander Terrane within Coast Plutonic Complex. B: Karst canyon along the Nakina River; likely hosted within Horsefeed carbonate unit of Cache Creek Terrane. C: Shafts in karst on Mount Sinwa hosted within limestone of the Sinwa Formation. D: Karst Lake near Atlin Lake; probably hosted within Horsefeed carbonate unit of Cache Creek Terrane. E: Karst ridge and bluffs with solutional openings, north of Fort St James. Karst hosted in massive limestone of the Cache Creek Group. F: Shallow depression/sinkhole near Jesmond. This feature likely occurs with limestone of the Marble Canyon Formation. 
and information on postglacial environments, which are important for developing ideas of human coastal migration (Ramsey et al. 2004; Al-Suwaidi et al. 2006).

Isolated areas of karst also occur along the mid- and northcoast of mainland BC. Many of these limestone areas are metamorphosed and occur as isolated roof pendants surrounded by the intrusive granodioritic rocks of the Coast Mountain Belt. These roof pendants are likely metamorphosed remnants of Alexander Terrane rocks and consist of small areas of limestone that are variably transformed to marble. Examples include the area around Chapple Inlet on Princess Royal Island, where numerous grike fields, intenselydeveloped epikarst exposures, and sinkholes occur (Stokes and Griffiths 2000b), and near Bella Bella (Fig. 9A). Karst areas also occur on the coast of the mainland BC opposite Vancouver Island, such as on the Sechelt Peninsula, where there are limestone zones with known caves. These are likely similar limestone and marble remnants of the Wrangellia Terrane, but knowledge of karst development in these areas is incomplete.

\section{Coast Belt}

The Coast Belt of BC and the corresponding Coast Mountains can be subdivided into the northwest Alsek Ranges, the northern Boundary Ranges, the central Kitimat Ranges and the southern Pacific Ranges. The Coast Mountains extend up to elevations of $2500-3000 \mathrm{~m}$ and are dissected by several large river systems that drain to the west (e.g. the Fraser, Skeena, Nass, Stikine and Taku rivers). Most of the Coast Mountains are comprised of granitoid rocks with small roof pendants of metamorphic rocks derived from the adjacent terranes.

Extensive areas of soluble bedrock occur in the far northwest of BC within the Alsek Ranges, which form much of the Tatshenshini-Alsek Provincial Park. This area is a northern extension of the karst lands of the Tongass National Forest of Southeast Alaska, which extends from Prince of Wales Island to Chichagof Island (Baichtal and Swanson 1996). The carbonate bedrock units within the Tatshenshini-Alsek Park underlie approximately $40-50 \%$ of the region and vary from massive Ordovician and Silurian limestone to mixed Silurian to Permian carbonate, clastic and volcanic sequences. Much of the Alsek Ranges occur in sub-alpine, alpine and glacial settings, with steep sideslopes that lead down to forested valley bottoms and the flood plains and tributaries of the Tatshenshini River system. The nature of the karst in this region is not well documented. However, several small elongate zones of gypsum (Chitistone Formation) are known to occur along a ridge line near O'Connor River, and include numerous large (10-20 m diameter) sinkholes (White 1985).

The northern part of the Coast Belt includes the lower reaches of the Taku, Stikine, Nass and Skeena River systems that are within the Boundary Ranges and abut the border of Southeast Alaska. Large areas of the Paleozoic Stikine Terrane occur along the lower reaches of the Stikine River and include limestone intermixed with other sedimentary and volcanic rocks. Further south along the lower part of the Nass River, limestone is present within the Unuk River Formation, and along the Skeena River, minor limestone and marble areas are present in metasedimentary rocks of the Alexander Terrane. Karst in this region is not well documented. However, several small Permian limestone areas occur near Kitimat and Terrace, within which small caves and other karst features have been investigated by one of the authors.

The southern part of the Coast Belt extends southward from the Skeena River to Chilliwack near the US border (Figs. $3,4)$. Small roof pendants of limestone with mixed sedimentary and volcanic rocks, representing parts of the Alexander, Nisling and Stikine terranes, occur within the granodiorite of the Coast Mountain batholith. To the south, numerous limestone zones, which are part of the Permian Chilliwack Formation, occur on the side slopes of the Chilliwack River. Caves and other karst features are known to occur in these limestone zones (Shaw 1997).

\section{Intermontane Belt}

The Intermontane Belt is comprised of a series of plateaus (Northern, Interior and Thompson plateaus) and small mountain ranges (e.g. the Skeena Ranges) that extend from the Yukon border southward to the Okanagan Valley. Geologically, the belt is mainly made up of the Stikine, Cache Creek and Quinella terranes, along with several other smaller terranes (Wheeler and McFeely 1991).

In the north, extensive carbonate bedrock units occur in the Atlin region of the Northern Plateau including the Horsefeed Formation, Lower Carboniferous-Triassic limestone with interbedded clastic sedimentary rocks, and black limestone of the Teslin Formation. These are all part of the Cache Creek Terrane. The Stikine Terrane includes the massive limestone of the Sinwa Formation and other Lower Permian limestone units. A karst inventory for the Atlin-Taku Planning Area (Griffiths 2009) identified over 400 karst features in these units and rated the areas for their karst vulnerability potential. The features encountered included numerous karst depressions, shafts, karst canyons, karst lakes, cave entrances, sinkholes and springs; as well as a large spring discharging into the Taku River (Fig. 9B, C and D). This karst inventory provided useful field verification of the karst potential polygons developed during the reconnaissance karst mapping for BC (Stokes 1999).

Areas of carbonate bedrock in the Chilcotin and Cariboo plateau regions include limestone of the Cache Creek Group in areas around Stuart Lake and Fort St James, and karst features and caves near the Mount Pope Provincial Park ${ }^{1}$ (Fig. 9E). Much of the carbonate bedrock in this region is overlain by thick glacial deposits that may mask the presence of some karst areas.

Caves, sinkholes and springs have been observed within the limestone areas of the Marble Canyon Formation northwest of Kamloops (Fig. 9F). Examples of these features and limestone cliffs are found within Marble Canyon Provincial Park, which

${ }^{1}$ For listings and information of caves and karst in British Columbia's Provincial Parks visit the link: http://www.env.gov.bc.ca/bcparks/explore/ 
is also known for primary stromatolite features at Pavilion Lake. To the south of Kamloops small limestone zones occur in volcanic and metasedimentary rocks of the Nicola and Harper Ranch Groups.

\section{Omineca Belt}

The Omineca Belt is a region of intermediate-elevation mountains located between the intermontane plateaus and the higher mountains of the Rockies, and represents an area of complex deformation underlain by multiple smaller amalgamated terranes (e.g. Cassiar, Slide Mountain and Kootenay terranes). The Omineca Belt is comprised of the Cassiar and Omineca mountains to the north, and the Columbia Mountains to the south. The Rocky Mountain Trench (Fig. 4) bound these three mountain ranges to the east.

In the Cassiar Mountains extensive areas of carbonate bedrock extend from the Yukon border southward along the west side of Williston Lake. These include the limestone of the Rosella and Espee formations (Cassiar Terrane), as well as impure limestone and dolostone that are part of the metamorphosed Ingenika and Kechika groups. A few karst features (e.g. springs) are known to occur in this area. East of Prince George in the northern Columbia Mountains carbonate bedrock units include the limestone and dolostone of the Mural and Cunningham formations, and other unassigned Paleozoic rocks. The Mural Formation is known to host caves in the Rocky Mountains (Rollins 2004).

In the central and southern part of the Columbia Mountains and extending southward from Valemount to Revelstoke and towards Kootenay Lake, discrete and narrow linear units of limestone and marble are present. These include marble of the Horsethief Group and limestone of the Badshot Formation, as well as minor limestone layers within metasedimentary units, such the Index and Broadview formations. This area is climatically different from other interior regions of $\mathrm{BC}$ in that it is distinctly wetter, with rainfall amounts and temperature conditions that are similar to the west coast of BC. The Nakimu Caves area and Mount Tupper within Glacier National Park have been classified as examples of steeply dipping 'stripe karst,' where karst develops in narrow and deformed beds of marble that are traceable for kilometres, but are only a few tens of metres wide (Gunn 2003). Ford (1967) connected a major spring in this stripe karst to sink points near the Tupper Glacier, and more recent work of Yonge et al. (2013) has extended the caves in this region. Other examples of stripe karst have been examined in the Monashee Mountains (Yonge 2018). Recently, a large cave entrance and an associated sinking stream were discovered within the Wells Gray Provincial Park and are reported to be in stripe karst (C. Hickson personal communication 2018). Similar limestone and dolostone 'stripes' occur with solutional weathered bedrock surfaces to the east of Argenta and at the north of Kootenay Lake (Stokes and Griffiths 2000b). Cody Caves Provincial Park on the east side of Kootenay Lake also occurs within the narrow limestone layers that are part of the Milford Formation. Sinkholes, springs and sinking streams were identified in this area around the main cave entrance (Stokes and Griffiths 2000b). Dolo- stone of the Index Formation is present on the west side of Kootenay Lake, near the Pilot Peninsula Provincial Park. In this area, there is evidence for minor surface solutional weathering, shoreline springs with tufa, and a rare limestone-loving orchid (Carver 2000; Stokes and Griffiths 2000b).

\section{Foreland Belt}

The Foreland Belt, which encompasses much of the Canadian Rocky Mountains, includes the most extensive areas of carbonate rocks in BC, and straddles the BC-Alberta border (Figs. $3,4)$. These carbonate rocks are Cambrian to Mississippian in age and represent uplifted platformal rocks that were originally deposited on ancestral North America, prior to the terrane collisions that occurred in the Mesozoic. The Canadian Rocky Mountains can also be subdivided into four topographic units going from east to west (the Foothills, Front Ranges, Main Ranges and Western Ranges) and can be subdivided from north to south. The Southern (Canadian) Rocky Mountains approximately extend from the US border to Valemount (BC) and Jasper (Alberta), whereas the Northern Rocky Mountains extend from Valemount and Jasper to the Yukon and Northwest Territories borders (Fig. 4).

A detailed review of karst in the Southern Rocky Mountains carried out by Ford (1979) identified the main karstforming carbonate units as the Cambrian Mural Formation (limestone) and Cathedral Formation (limestone, dolostone), the Upper Ordovician and Silurian Mount Wilson and Beaverfoot formations (limestone, cherty dolostone), the Upper Devonian Palliser Formation (limestone, dolostone), and the Mississipian Rundle Group (Table 2). Ford (1979) also investigated surface karst landform types and their relationships to glacial processes which formed features such as over-deepened cirques with underground drainage, and solutionally-enlarged fractures in frost-shatter zones. One of the major caves in the Foreland Belt is Castleguard Cave, which is partly below the Columbia Icefield, and located just to the east of the $\mathrm{BC} /$ Alberta border. The cave system is hosted in limestone of the Cathedral Formation and has more than $21 \mathrm{~km}$ of mapped underground passageways. Basal meltwaters from the icefields drain through these passageways, some of which are blocked by ice or till material (Smart 1983; Yonge et al. 2014; Ford and Smart 2017).

Caves in the Southern and Northern Canadian Rocky Mountains are well documented in a book by Rollins (2004) and identified nine cave and karst areas on the $\mathrm{BC}$ side of the Southern Rocky Mountains, including Kootenay and Yoho National Parks, the Hamber, Mount Robson, and Small River caves, and Kakwa and Mount Robson Provincial Parks. Karst areas also occur near Golden and at Rogers Pass. Karst plateaus, limestone pavements and springs with associated sinking streams and sinkholes (Fig. 8A, B, E and F) characterize these areas. Many of the caves have entrances that occur at the base of vertical shafts or springs. Some of the caves have considerable depth, such as Arctomys Cave in the Mural Formation within Mount Robson Provincial Park, which has a reported depth of $536 \mathrm{~m}$ (Rollins 2004). A cave with a depth of $670 \mathrm{~m}$ was recently found near Mount Bisaro north of Fer- 
nie, $\mathrm{BC}$, and is currently considered to be the deepest in North America (Genairon 2018).

The Northern Rocky Mountains generally have more dolostone units than the Southern Rocky Mountains. Some of the more extensive carbonate bedrock units include the limestone of the Ketchika, Cache Creek and Rundle groups, as well as the limestone and dolostone of the Mural, Lynx, Dunedin, Stone, Prophet, Nonda, Chushina, Cunningham and Espee formations.

A cave and karst resource evaluation carried out for the Muskwa-Kechika Planning Area (Safford 2000) identified five karst areas including the Liard River (karst springs along river), the Toad River-Racing River area (cliffs with cave entrances), the Through Creek area (cave entrances along Gataga Creek), the Redfern Lake (large sinking streams and depressions) and the Chowade River (a series of large, kilometre-size depressions and sinks). Karst is mostly developed in the Espee, Baldonnel, Pardonnet and Dunedin formations.

Southeast of Chetwynd, a major spring within the Hole-inthe-Wall Provincial Park emerges from the base of limestone bluffs of the Rundle Group (Fig. 7E), but no other surface karst features of note were identified in nearby areas (Stokes and Griffiths 2000b). In the Club Creek - Imperial Creek area, a large sinkhole and other small isolated karst features were encountered (Fig. 7F). This area is masked by thick glacial deposits, but is likely underlain by limestone of the Whitehorse Formation. Further south in the Monkman Provincial Park, karst features include several small caves, a spring and karst sinkholes. This park is underlain by dolostone of the Skoki and Beaverfoot formations, as well as limestone of the Chushina Formation.

Numerous caves occur in the Northern Rocky Mountains, mainly in the McGregor Ranges and the Dezaiko Ranges, as well as in the Kakwa, Bocock and Bowron Lakes Provincial Parks (Lowe 1985; Rollins 2004). Many of these cave and karst areas are difficult to access and occur as higher elevation limestone plateaus with cave entrances, sink points and shafts, along with karst springs at lower elevations.

\section{KARST TYPES AND KARST DEVELOPMENT WITHIN BC}

Karst within the various tectonic and physiographic regions of $\mathrm{BC}$ is broadly similar having subsurface drainage systems, surface solutional weathering and a range of other karst features. However, there can regionally be significant differences in the intensity of karst development and the distribution and types of karst features encountered, due to variations in carbonate bedrock geology, surficial cover, current climate conditions, types of vegetation and extent of forest cover and the influence of glaciation. These contrasts and differences act in combination to produce the variety of karst types across the province. Figure 10 provides a schematic profile from east to west across the province outlining some of these variations. This figure is, in part, based on a series of models suggested by Ford (2002), who identified three distinct structural settings for BC's karst: 1) the gently tilted limestone and dolostone units associated with thrust faults within the Rocky Mountains, 2) the steeply dipping marble and limestone units immediately west of the Rocky Mountains, and 3) the moderately to steeply dipping limestone units on the west coast.

Coastal BC is dominated by forest-covered islands and mountains. Forest-covered karst or more precisely 'coastal temperate forested karst' is the dominate karst type in this region, where conifers like western hemlock, amabilis fir (balsam) and western red cedar flourish and have a close intimate connection to the underlying karst. The term 'coastal temperate forested karst' is used to differentiate this type of karst from the forested karst that occurs in generally drier climatic zones to the east. Most of the coastal temperate forested karst occurs on slopes or benches within moderately to steeply dipping and faulted limestone units that are interlayered with volcanic sequences. Solutional weathering and karren are apparent on all exposed limestone outcrops that are part of well-developed epikarst exposures. Numerous sinkholes and other surface karst features (e.g. solution holes, shafts, karst canyons) are also common. Active subsurface drainage systems are usually present with associated sinking streams and karst springs. River caves (e.g. Artlish Caves, Little Huson Caves) can also be found. Many of the coastal temperate forested karst areas have significant allogenic recharge, with surface streams from nonkarst catchments draining down onto the karst areas. In higher elevation areas (e.g. $>1200 \mathrm{~m}$ a.s.l.) subalpine to alpine karst occurs with well-developed surface solutional weathering on exposed ridges (e.g. White Ridge Provincial Park). In these areas, subsurface drainage systems are autogenically recharged by precipitation falling directly onto and vertically infiltrating into the karst. Coastal temperate forested karst and subalpine to alpine karst are likely the main types of karst that occur within the Coast Mountains, but these areas have not been extensively documented.

Forested karst occurs on the plateaus and mountainous regions within the $\mathrm{BC}$ interior, where limestone units are mainly interlayered with volcanic units, and in the north where they are associated with both volcanic and sedimentary sequences. Many of the southern regions are drier and mantled by thick glacial deposits. Surface karst development is less evident in these areas. However, isolated sinkholes and other karst features, such as karst springs, indicate the underlying presence of subsurface drainage systems. This type of 'covered karst' is not well documented, but is likely present in several areas based on the mapped distribution of limestone units in the region (e.g. near Kamloops and Prince George). Some uplifted limestone areas, such as the Pavilion Mountain, form highlands that exhibit evidence for karst development, but not of the intensity observed along the coast. Much of these highlands are forest-covered. Forest-covered karst extends into the central and northern parts of the $\mathrm{BC}$ interior which are dominated by subboreal spruce and pine forests; alpine karst likely occurs in some of the more mountainous areas.

Stripe karst is the principal karst type in the Columbia Mountains of the Omineca Belt, where thin and steeply dipping limestone (marble) layers occur in deformed metamorphic rocks. This karst varies from forest-covered to subalpine and alpine and is well developed, with sinking streams, springs and cave systems. This southwest region of BC has a wetter 


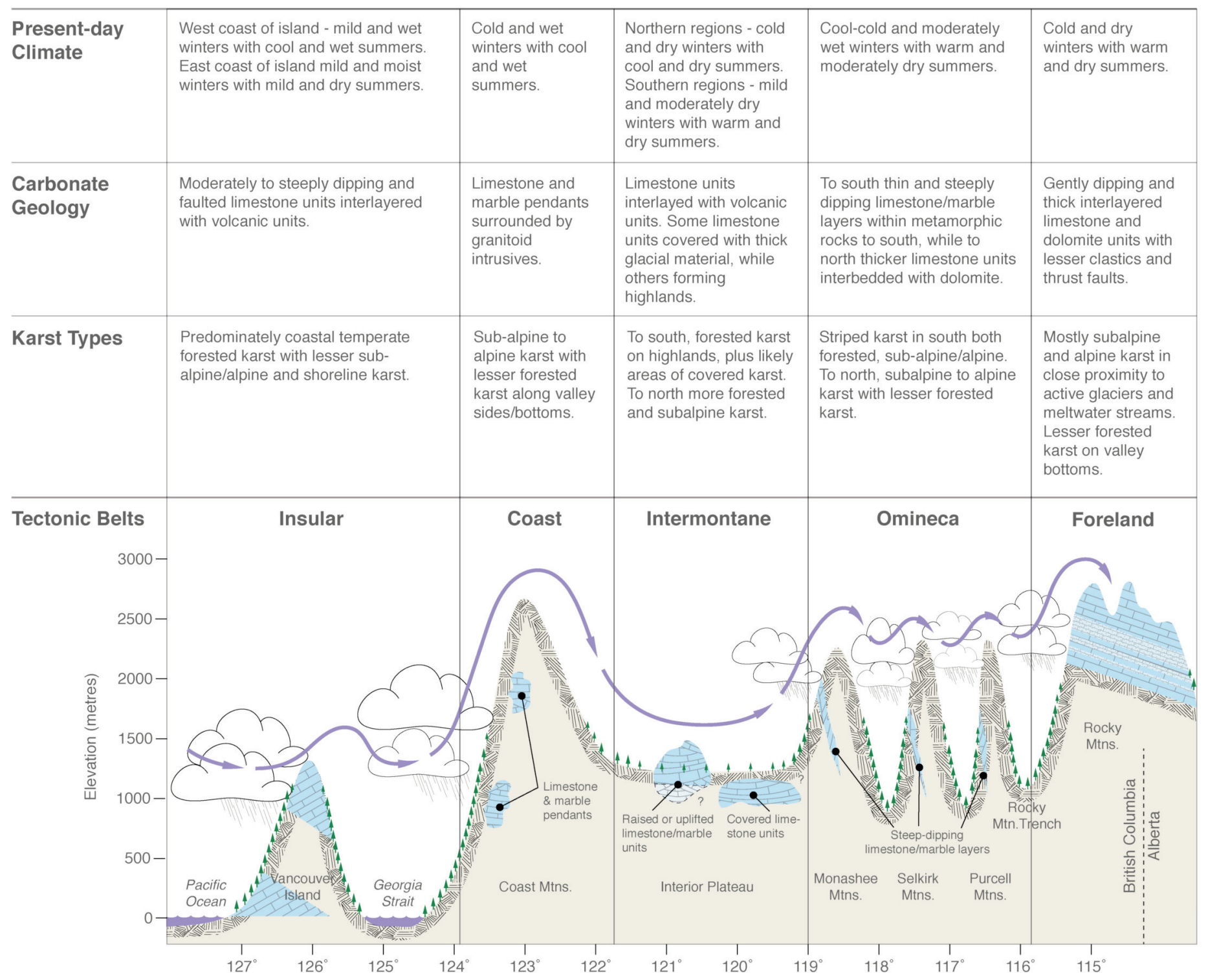

Figure 10. Schematic profile across southern British Columbia illustrating karst types along with respective climatic conditions and carbonate bedrock geology. Adapted from Chilton (1981) and Moore et al. (2010).

climate than the interior and is similar in part to the coast. Allogenic recharge is dominant, which is typical for stripe karst. To the north, in the Omineca and Cassiar Mountains, thicker limestone units are present and are interbedded with dolostone and fine-grained clastic sequences. Subalpine to alpine karst is likely the main karst type in this region.

Karst in the Rocky Mountains occurs within thrusted and gently dipping limestone and dolostone units that form thick sedimentary sequences, and for the most part subalpine or alpine karst is dominant. In these areas considerable surface solutional weathering has occurred on glacially-scoured limestone pavements, and frost shattering of bedrock has obscured surface karst features such as sinkholes. Most the subsurface karst drainage in this region is recharged autogenically by the diffuse infiltration of melt waters from snow or glaciers. Many of these caves are accessed through vertical openings and shafts, or through karst springs.

Unravelling the karst development history and associated processes in BC requires not only an understanding of how soluble bedrock types take on the characteristics of karst, but also consideration of landscape erosion rates, present and past climate conditions, tectonic processes and uplift, sea level changes, and glaciation. The initiation of karst development (i.e. when it first formed) and likewise its end (or cessation) remain open to interpretation and discussion (Ford 2002). In general, the initiation of subsurface conduits in karst can take 1000 to 10,000 years before it becomes a fully functioning underground drainage system (Palmer 2007). The timing of cessation is more obvious and tied to erosion and final removal of a karst landscape. Information from cave contents, such as 
speleothem and sediment, does not directly provide ages for cave and karst development, but they give some idea on when such materials formed and can thus provide preliminary constraints on cave histories. Castleguard Cave in the Rocky Mountains contains speleothems formed 340,000 to 350,000 years ago, and the oldest speleothem may be as old as 780,000 years, based on uranium series ages (Ford et al. 1981; Gascoyne et al. 1983). More recent uranium-series dating from Rat's Nest Cave in the Rocky Mountains has provided ages of 780,000 years to modern (Yonge 2012). These speleothem ages are thought to match the punctuated glacial record of the Rocky Mountains, suggesting that most speleothem growth occurred during major interglacial periods. The speleothem ages from the Rocky Mountain caves are much older than two groups of uranium-series ages reported from Cascade Cave on Vancouver Island, where speleothems formed at 64,000-45,000 years and later than 15,000 years, respectively (Gascoyne et al. 1981). These speleothem ages can be linked to interglacial Olympia and Fraser events. Age estimates of up to 140,000 years were suggested for Horne Lake Cave based on repeated and overlapping periods of speleothem formation, sediment infilling and cave development (Ford 1975).

The limited geochronological data cited above suggest that some caves in the Rocky Mountains formed speleothems prior to those of Coastal BC. However, without more extensive data, it is difficult to speculate how these ages exactly tie into the ages of cave formation, and when these karst landscapes might have initially developed. The coast, with its greater density of cave and karst features, is a region where karst development is an ongoing process, primarily due to its more temperate maritime climate. The karst features observed at the present-day surface largely result from solutional activity following the end of the last glacial period (12,000 years ago) and are likely superimposed on older 'relict' karst, which is possibly responsible for the deeper cave systems and larger surface features (e.g. Devil's Bath). The influence of the last glacial ice sheet margin along the west coast may also have enhanced surface and subsurface karst development during ice-sheet melting, runoff and isostatic rebound (Ford 1987). More subdued surface karst development in the interior of $\mathrm{BC}$ is likely due to lower precipitation rates and the thicker cover by glacial materials. However, this should not preclude earlier development of subsurface hydrological systems, as evident from the presence of large and (sometimes isolated) karst springs. Karst development in the Rocky Mountains is likely the result of multiple episodes of dissolution that alternated with glacial events that eroded and infilled the karst surface, and possibly enhanced subsurface flows during ice-sheet melting (Ford 1983b). Many caves in the Rocky Mountains have passages that may be preglacial, as indicated by conduit size and their glacial truncation on high ridges (Yonge et al. 2014). These caves likely represent the roots of older karst systems that have been uplifted from lower elevations and eroded. In summary, there is still much to discover with respect to the history and processes of cave and karst development in $\mathrm{BC}$.

\section{NEXT STEPS FOR KARST MANAGEMENT AND MAPPING IN BRITISH COLUMBIA}

The general approach to karst management in $\mathrm{BC}$ has changed in the last 20 years, in that karst resources and values are now better recognized and are being examined in relation to landuse issues beyond forestry (i.e. oil and gas development, alternative energy projects and mining activities; Stokes 2013). Many of these changes reflect recognition of karst as an integrated system with distinctive hydrology and biology, along with a greater appreciation of its scientific, recreation and other values. The potential for karst hazards, such as subsidence and unpredictable subsurface water flows, on development activities has also become more recognized and understood (Zhou and Beck 2011; Parise 2015). However, there is less attention paid to the equally important non-karst catchments and streams that drain onto these karst areas, where they recharge karst aquifers and move groundwater by subsurface conduits to karst springs. Land-use impacts on these non-karst catchments are sometimes overlooked but can have a major impact on downstream karst systems. Careful mapping, assessment and management of non-karst catchments is essential (Gillieson 1996; Watson et al. 1997). Buried or covered karst is also a potential concern, because subsurface openings and associated underground hydrology may occur without any apparent surface manifestation (Veress 2016).

Karst, and its associated aquifers, are globally significant, and require careful consideration in the context of climate change. British Columbia has limited dependence on karst aquifers as a domestic water source, but many river systems are supplied by waters obtained in part from karst regions (e.g. Northern Vancouver Island, Canadian Rocky Mountains). Some rivers and their associated habitats are thus dependent on karst water, which may potentially be important for aquatic productivity and fish populations (e.g. Bryant et al. 1998). In alpine karst regions, the ongoing retreat of glaciers will likely expose more karst areas and increase meltwater flow, changing flow paths within karst aquifers and affecting water that is contributed to streams and lakes down gradient.

Outlining the full extent and nature of karst landscapes in $\mathrm{BC}$ is still incomplete. One of the major difficulties with mapping karst in $\mathrm{BC}$ is the extensive forest cover that obscures the location of many surface karst features. LiDAR data has successfully been used to better identify karst in forested areas (Langendoen and Baichtal 2004), but are currently not widely available in BC. The 1999 Reconnaissance Karst Potential Mapping for BC attempted to identify all karst and potential karst areas within the region (Stokes 1999); however, it now warrants updating considering the new digital bedrock mapping database available for the province (Cui et al. 2017), the greater accessibility of satellite imagery (e.g. Google Earth) and increased knowledge of karst field sites. Efforts should now be made to better integrate this revised mapping with published and unpublished reports on karst sites within the province. In addition, the map information should be made more easily available and accessible to users (e.g. developed as .kmz files for Google Earth) and in formats suitable for tablet and smart phone use. 


\section{ACKNOWLEDGEMENTS}

Dr Carol Ramsey of Campbell River (BC), and Dr Chas Yonge of Canmore (Alberta) are acknowledged for their considerable effort and time in providing discussions, materials and reviews of this paper. Much of the information on karst in the Rocky Mountains was supplied by Dr Chas Yonge. Thanks should also be given to the three anonymous reviewers from Geoscience Canada for their useful feedback. The considerable efforts of the Geoscience Canada editors in revising the text and figures is also recognized.

\section{REFERENCES}

Al-Suwaidi, M., Ward, B.C., Wilson, M.C., Hebda, R.J., Nagorsen, D.W., Marshall, D., Ghaleb, B., Wigen, R.J., and Enkin, R.J., 2006, Late Wisconsinan Port Eliza cave deposits and their implications for human coastal migration, Vancouver Island, Canada: Geoarchaeology, v. 21, p. 307-332, https://doi.org/10.1002/ gea.20106.

Baichtal, J.F., and Swanston, D.N., 1996, Karst landscapes and associated resources: a resource assessment: U.S. Department of Agriculture and Forest Service, Pacific N.W. Research Station, Portland, Oregon. General Technical Report PNW-GTR-383.

BC Ministry of Forests, 1997, A complex landscape sculpted by water (Brochure): British Columbia Ministry of Forests, Forest Practices Branch. Available at: http://www.for.gov.bc.ca/hfp/publications/00192/.

BC Ministry of Forests, 2003, Karst management handbook for British Columbia: British Columbia Ministry of Forests, Research Branch, Victoria, BC, 81 p., Available at: http://www.for.gov.bc.ca/hfp/publications/00189/Karst-MgmtHandbook-web.pdf.

Beedle, B., 1997, Management of karst in British Columbia: Proceedings of 1997 Karst and Cave Management Symposium, Bellingham, Washington, p. 13-21.

Bryant, M.D., Swanston, D.N., Wissmar, R.C., and Wright, B.E., 1998, Coho salmon populations in the karst landscapes of North Prince of Wales Island, Southeast Alaska: Transactions of the American Fisheries Society, v. 127, p. 425-433, https://doi.org/10.1577/1548-8659(1998)127<0425:CSPITK>2.0.CO;2.

Carver, M., 2000, Hydrologic assessment, Pilot Peninsula study area: Prepared for British Columbia Parks Kootenay District, 18 p.

Chilton, R.H., 1981, Summary of climate regions of British Columbia: British Columbia Ministry of Environment, Victoria, BC, 46 p.

Church, M., and Ryder, J.M., 2010, Physiography of British Columbia, in Pike, R.G., Redding, T.E., Moore, R.D., Winkler, R.D., and Bladon, K.D., eds., Compendium of Forest Hydrology and Geomorphology in British Columbia: British Columbia Ministry of Forests and Range, Handbook 66, Kamloops, BC, p. 17 46.

Cui, Y., Miller, D., Schiarizza, P., and Diakow, L.J., 2017, British Columbia digital geology: British Columbia Ministry of Energy, Mines and Petroleum Resources, British Columbia Geological Survey Open File 2017-8, 9 p.

Ecock, K., 1984, The hydrology of an alpine karst: White Ridge, Vancouver Island: Unpublished MSc thesis, McMaster University, Hamilton, ON, 138 p.

Fischl, P., 1992, Limestone and dolomite resources in British Columbia: British Columbia Ministry of Energy, Mines and Resources, Mineral Resources Division, Geological Survey Branch, Open File 1992-18, 150 p.

Ford, D., 1987, Effects of glaciations and permafrost upon the development of karst in Canada: Earth Surface Processes and Landforms, v. 12, p. 507-521, https://doi.org/10.1002/esp.3290120508.

Ford, D.C., 1967, The sinking streams of Mt. Tupper - a remarkable karst in Glacier National Park, B.C.: Canadian Geographer, v. XI, p. 49-52.

Ford, D.C., 1975, Report on the Euclatawes-Main Cave System of Horne Lake Caves Provincial Park, Vancouver Island: Unpublished report completed for Parks Branch, Department of Recreation and Conservation, British Columbia, $30 \mathrm{p}$.

Ford, D.C., 1979, A review of alpine karst in the southern Rocky Mountains of Canada: National Speleological Society Bulletin, v. 41, p. 53-65.

Ford, D.C., 1983a, Effects of glaciation upon karst aquifers in Canada: Journal of Hydrology, v. 61, p. 149-158, https://doi.org/10.1016/0022-1694(83)90240-8.

Ford, D.C., 1983b, The physiography of the Castleguard karst and Columbia Icefields area, Alberta, Canada: Arctic and Alpine Research, v. 15, p. 427-436, https://doi.org/10.1080/00040851.1983.12004371.

Ford, D.C., 1993, Karst in cold environments, in French, H.M., and Slaymaker, O., eds., Canada's Cold Environments: McGill-Queen's University Press, p. 199 222.

Ford, D.C., 2002, From pre-karst to cessation: the complicating effects of differing lithology and geologic structure on karst evolution, in Gabrovšek, F., ed., Evolution of Karst: From prekarst to cessation: Littera picta, Ljubljana, Slovenija, p. $31-42$.
Ford, D.C., and Smart, C.C., 2017, Castleguard Cave and Karst, Columbia Icefield, Alberta and British Columbia, in Slaymaker, O., ed., Landscapes and Landforms of Western Canada: Springer, Switzerland, p. 227-239, https://doi.org/ 10.1007/978-3-319-44595-3_16.

Ford, D.C., Schwarcz, H.P., Drake, J.J., Gascoyne, M., Harmon, R.S., and Latham, A.G., 1981, Estimates of the age of the existing relief within the southern Rocky Mountains of Canada: Arctic and Alpine Research, v. 13, p. 1-10, https://doi.org/10.2307/1550621

Gascoyne, M., Ford, D.C., and Schwarcz, H.P., 1981, Late Pleistocene chronology and paleoclimate of Vancouver Island determined from cave deposits: Canadian Journal of Earth Sciences, v. 18, p. 1643-1652, https://doi.org/10.1139/ e81-152.

Gascoyne, M., Latham, A.G., Harmon, R.S., and Ford, D.C., 1983, The antiquity of Castleguard Cave, Columbia Icefields, Alberta, Canada: Arctic and Alpine Research, v. 15, p. 463-470, https://doi.org/10.2307/1551233.

Genairon, J., 2018, Bisaro Anima: la cavité la plus profonde du Canada: Sous Terre Société Québécoise de Spéléologie, v. 27, No. 1, p. 12-15.

Gillieson, D., 1996, Caves: Processes, Development, Management: John Wiley \& Sons, Ltd., 324 p., https://doi.org/10.1002/9781444313680.

Griffiths, P.A., 2009, Atlin-Taku Planning Area: Report on karst resources: Unpublished report prepared for British Columbia Ministry of Agriculture and Lands, Integrated Land Management Bureau Smithers, BC, 21 p.

Griffiths, P.A., and Ramsey, C.L., 2009, Assessment of Forest Karst Resources of Haida Gwaii: A Strategic Overview: Gwaii Forest Society, Project SFM08-2008, $57 \mathrm{p}$.

Gunn, J., (editor), 2003, Encyclopedia of Caves and Karst Science: Fitzroy Dearborn, New York, 960 p., https://doi.org/10.4324/9780203483855.

Harding, K.A., and Ford, D.C., 1993, Impacts of primary deforestation upon limestone slopes in northern Vancouver Island, British Columbia: Environmental Geology, v. 21, p. 137-143, https://doi.org/10.1007/BF00775297.

Harmon, R.S., Ford, D.C., and Schwarcz, H.P., 1977, Interglacial chronology of the Rocky and Mackenzie Mountains based upon ${ }^{230} \mathrm{Th}-{ }^{234} \mathrm{U}$ dating of calcite speleothems: Canadian Journal of Earth Sciences, v. 14, p. 2543-2552, https://doi.org/10.1139/e77-220.

Langendoen, R.R., and Baichtal, J.F., 2004, Using LIDAR remote sensing to map karst topography in a temperate rain forest - Case study: Tongass National Forest, southeastern Alaska: Geological Society of America Abstracts with Programs, v. 36, p. 385.

Latham, A., Schwarcz, H.P., Ford, D.C., and Pearce, G.W., 1982, The paleomagnetism and U-Th dating of three Canadian speleothems: evidence for the westward drift, 5.4-2.1 ka BP: Canadian Journal of Earth Sciences, v. 19, p. 19851995, https://doi.org/10.1139/e82-176.

Lowe, D.J., 1985, Karst development and cave formation in the Bocock Peak karst, Canada: Cave and Karst Science, v. 12, p. 33-44.

Marshall, D., Ghaleb, B., Countess, R., and Gabities, J., 2009, Preliminary paleoclimate reconstruction based on a 12,500 year old speleothem from Vancouve Island, Canada: Stable isotopes and U-Th disequilibrium dating: Quaternary Science Reviews, v. 28, p. 2507-2513, https://doi.org/10.1016/j.quascirev. 2009.05.019.

Mills, W., 1981, Karst development and groundwater flow in the Quatsino Formation, Northern Vancouver Island: Unpublished MSc thesis, McMaster University, Hamilton, ON, 183 p.

Moore, R.D., Spittlehouse, D., Whitfield, P., and Stahl, K., 2010, Weather and Climate, in Pike, R.G., Redding, T.E., Moore, R.D., Winkler, R.D., and Bladon, K.D., eds., Compendium of Forest Hydrology and Geomorphology in British Columbia: British Columbia Ministry of Forests and Range, Handbook 66, Kamloops, BC, p. 47-84.

Palmer, A.N., 2007, Cave Geology: Cave Books, Dayton, OH, 454 p.

Parise, M., 2015, Karst geo-hazard: Causal factors and management issues: Acta Carsologica, v. 44, p. 401-414.

Ramsey, C.L., 2015, Morphometry and basic ecological characteristics of dolines in unlogged temperate rainforests karst landscapes of Northern Vancouver Island, British Columbia, Canada: Unpublished PhD thesis, University of Nova Gorica, Slovenia, $316 \mathrm{p}$.

Ramsey, C.L, Griffiths, P.A., Fedje, D.W., Wigen, R.J., and Mackie, Q., 2004, Preliminary investigation of a late Wisconsinan fauna from K1 cave, Queen Charlotte Islands (Haida Gwaii), Canada: Quaternary Research, v. 62, p. 105-109, https://doi.org/10.1016/j.yqres.2004.05.003.

RISC. Resources Information Standards Committee, 2003, Karst Inventory Standards and Vulnerability Assessment Procedures for British Columbia: British Columbia Ministry of Forests, Victoria, BC, 109 p.

Rollins, J., 2004, Caves of the Canadian Rockies and Columbia Mountains: Rocky Mountain Books, p. 236 
Safford, K., 2000, Cave and karst resources of the Muskwa-Kechika Management Area: Muskwa-Ketchika Advisory Board, Unpublished report, Fort St John, $\mathrm{BC}, 32 \mathrm{p}$.

Shaw, P., 1997, Chilliwack Valley Field Trip Guide: Proceedings of 1997 Karst and Cave Management Symposium, Bellingham, Washington, p. 201-207.

Smart, C.C., 1983, The hydrology of the Castleguard Karst, Columbia Icefields, Alberta, Canada: Artic and Alpine Research, v. 15, p. 471-486, https://doi.org/10.2307/1551234.

Smart, C.C., 1997, Hydrogeology of glacial and subglacial karst aquifers: Small River, British Columbia, Canada: Proceedings of the $6^{\text {th }}$ Conference on Limestone Hydrology and Fissured Media, p. 315-318.

Stokes, T.R., 1995, Reconnaissance karst potential mapping for Vancouver Island: British Columbia Ministry of Forests, Nanaimo, BC. Unpublished report and maps.

Stokes, T.R., 1999, Reconnaissance karst potential mapping for British Columbia: British Columbia Ministry of Forests, Research Branch, Victoria, BC. Report and digital maps available from: https://catalogue.data.gov.bc.ca/dataset/ reconnaissance-karst-potential-mapping.

Stokes, T.R., 2013, The challenges of identifying, evaluation and managing British Columbia karst lands: Innovation Magazine, Journal of the Association of Professional Engineers and Geoscientists BC, March/April 2013, p. 16-20.

Stokes, T.R., and Griffiths, P.A., 2000a, A preliminary discussion of karst inventory systems and principles (KISP) for British Columbia: British Columbia Ministry of Forests, Research Branch, Victoria, BC, Working Paper 51, 124 p.

Stokes, T.R., and Griffiths, P.A., 2000b, Karst inventory and sensitivity/vulnerability field trials in British Columbia: British Columbia Ministry of Forests, Research Branch, Victoria, BC, Unpublished Report, 68 p.

Stokes, T.R., Griffiths, P.A., and Ramsey, C., 2010, Geomorphology, hydrology and management of karst landscapes in British Columbia, in Pike, R.G., Redding, T.E., Moore, R.D., Winkler, R.D., and Bladon, K.D., eds., Compendium of Forest Hydrology and Geomorphology in British Columbia: British Columbia Ministry of Forests and Range, Handbook 66, Kamloops, BC, p. 373-400.

Stokes, T.R., Ramsey, C.L., and Griffiths, P.A., 2013, Constraints for karst landscape evolution on Vancouver Island, British Columbia, Canada: Concepts, research plans and outcomes: Proceedings for the $20^{\text {th }}$ Australasian Cave and Karst Management Association Conference, Waitomo, New Zealand, p. 124-140.

Watson, J., Hamilton-Smith, E., Gillieson, D., and Kiernan, K., 1997, Guidelines for cave and karst protection: IUCN -The World Conservation Union, Cambridge, $\mathrm{UK}, 53 \mathrm{p}$.

Weary, D.J., and Doctor, D.H., 2014, Karst in the United States: A digital map compilation and database: USGS Open-File Report 2014-1156, 23 p.

Wheeler, J.O., and McFeely, P., 1991, Tectonic assemblage map of the Canadian Cordillera and adjacent parts of the United States of America: Geological Survey of Canada, "A" Series Map 1712A, (2 sheets), https://doi.org/10.4095/ 133549 .

White, G.V., 1985, Preliminary report, O’Connor River Gypsum Deposit (114P/10E): British Columbia Geological Survey Fieldwork 1985, p. 279-282.

Wigley, T.M.L., Drake, J.J., Quinlan, J.F., and Ford, D.C., 1973, Geomorphology and geochemistry of a gypsum karst near Canal Flats, British Columbia: Canadian Journal of Earth Science, v. 10, p. 113-129, https://doi.org/10.1139/e73-014.

Worthington, S.R., 1991, Karst hydrology of the Canadian Rocky Mountains: Unpublished PhD thesis, McMaster University, Hamilton, ON, 406 p.

Worthington, S.R., and Ford, D.C., 1995, High sulfate concentrations in limestone springs: An important factor in conduit initiation?: Environmental Geology, v. 25, p. 9-15, https://doi.org/10.1007/BF01061825.

van Beynen, P.E., (editor), 2011, Karst Management: Springer Science, Dordrecht, NL, 489 p., https://doi.org/10.1007/978-94-007-1207-2.

Veress, M., 2016, Covered Karsts: Springer Science, Dordrecht, NL, 536 p., https://doi.org/10.1007/978-94-017-7518-2.

Yonge, C.J., 2012, Under Grotto Mountain: Rat's Nest Cave (2 ${ }^{\text {nd }}$ Edition): Rocky Mountain Books, Surrey, BC, 152 p.

Yonge, C.J., 2018, The White Rabbit Marble Cave, Monashee Mountains, BC, Canada: A Cave System in Stripe Karst: $28^{\text {th }}$ BCRA Cave \& Karst Symposium, P. 17 18.

Yonge, C.J., Vieira, N., and Walker, A., 2013, The Tupper - Raspberry Rising Cave System: A remarkable example in Stripe Karst: $16^{\text {th }}$ International Congress of Speleology, 2013 ICS Proceedings, BRNO Czech Republic, p. 158-163.

Yonge, C.J., Bruns, H., Corlett, A., Graham, K., Horne, G., Lavigne. J., Lowe, D.J., McKenzie, I., Pollack, J., and Safford, K., 2014, Mountainous karst of the Canadian Rockies and Columbia Mountains: Abstract in Proceedings of Geological Society of America, Vancouver, BC, p. 392.

Zhang, R., Schwarcz, H.P., Ford, D.C., Schroeder, F.S., and Beddows, P.A., 2008, An absolute paleotemperature record from 10 to $6 \mathrm{Ka}$ inferred from fluid inclusion
$\mathrm{D} / \mathrm{H}$ ratios of a stalagmite from Vancouver Island, British Columbia, Canada: Geochemica et Cosmochimica Acta, v. 72, p. 1014-1026, https://doi.org/ 10.1016/j.gca.2007.12.002

Zhou, W., and Beck B., 2011, Engineering issues on karst, in van Beynen, P., ed., Karst Management: Springer Science, Dordrecht, NL, p. 9-45, https://doi.org/ 10.1007/978-94-007-1207-2_2.

\section{Received July 2018}

Accepted as revised February 2019 